MF. B. D. Stewart

Commisstoner of isl nee

Juneru, Alaska

Dear idr. Stewart:

Enclosed ia a short report on the Potter Limestone

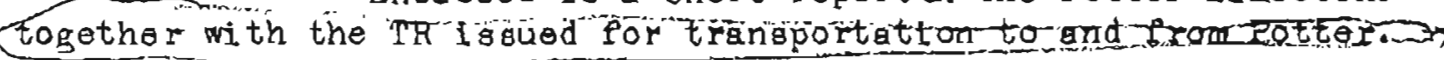

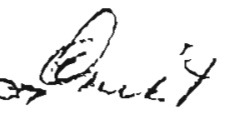

I Tae surely disappointed in not being ablo to get more information than I did. The appearance of the countryaide there from the alr and the train is very decelving. Actual inapection of the area prover that conelderable time would heve to bo apent in go ing around neighborhood, and a difelleult time will be had even at that because of the thick underbrugh, and profluaton of depli cluba, a well as the ooggy and swampy underfooting.

After an exhausting geved hours of pushing thru the brush, I hare not much more than a generaI idea of the layout of the outcrop in relation to the reilrosd and the mountein olope to the east.

The area to the west of the elsin and extending to

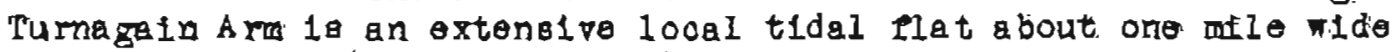
and 3 miles long(north to south) across which the raflyogd hes a fllled in road bod. The road bod has caused awamp rogetation to grow and inoreas the mater hold th place onet of the rail road. Only at extrem high tide does the Turnagain Arm peter oover thl portion of the flat. Nurorous a reas of rinte powder oover the drter parta of the Plat efter l.t has been out of rater for anhile. This might indicate that the run-off water from the benoh has a higher amount of alcium in golution than to to bo found eleerhere.

In ang event, conelderable prospecting will be necesaary before any appeciable smount of information can be obtained and which will be nocesary to plan a program of explattation of the doposit.

Potter section hand s clatu that there have been bereral propapectore in the pat who have oought gold at different pointo above the clatm on the bench, and furthor back from the rall road. Tro men on the esction gang eald that they had visited soveral amall adite and trenches earlier in the opring when the anow wag boginaing to melt. One of the men said that the allt $\mathrm{w}$ we in rock gimilar to that to the south of Potter (groonstone), and some wero in rock similar to that a round Portage Junction (alate and greyracke). These men clala to heve heard that wire silver had been found in quartz atringers in one place.

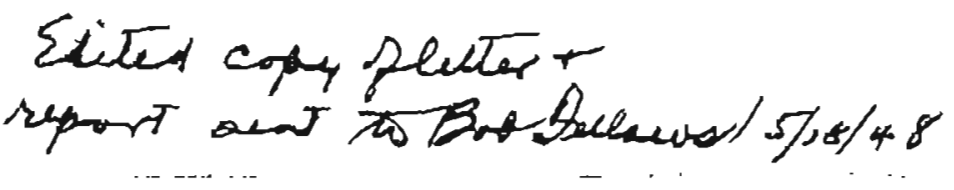


As this area is just over the hill from the itrowood district, lt may well be that the rineralization may be continuod weat to some extent. Thts mey make it worth while to tnvestigate at oo $a \theta$ future tine.

Soro daya ago, A. B. Smith cato in to tell wa the olt'ation in regards to the property that he and Clyde slags, Slleo Punker (recently deceresed), and $\dot{x}$. C. Crown optioned from Conn and John Carleon on yaldez creek. Thle group patd down some unstated amount, and are to complete peyment in about 5 years. They have formed the "Intertor MinIng, Drlling Doveloping Co., capital - \$100,000, par value 100 per shere. About $65 \%$ of the etsck has been sold an 1 is held by the 4 organLzers. A bout 9 niles of clalms are held on "raldez Creek. At present, A. C. Crown 18 in chargo of the test drilling of 12 hole日, and the later drilling of about 12 more holes. iecording to Smith, an order has been placed for a juber dredge, 500 tons, whth 5 foot bucket a and able to dig 110 peet. They expect to dig at about 50 feet. aravel is running about 90\% a yard. It 1a hoped that they will be in operation by next eurmer if all goeg well.

Clark $\therefore$. Sulth who has several claima weat of tho "ahil tha sivar and lntend a to go in and locato moro thio sumer, wo in looking for naps of that section. "one are avallable so he will still have to rely on his sncient "roll mep.

Johr ilaynes and Carl thomes, Box 877, : oward brought in four samoles of rock and quartz for asoying. from a claim which they had located on Firat Street in Semard, at the bage of lount Marathon. The samples have not bean run jet so the rosulte are not known both

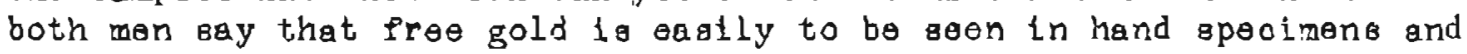
that panning indlcates to easily. They have eunk a ten foot shaft. It seems that the surface ha been hometeaded by Senator Browell, or rether he owns it and questions their right to mine. They do not know of their righte, and offered to make an agreement with him. in his insiatence on a $25{ }^{\circ}$ r rayalty, whlch they refueed to give, they came in to Anchorage to get advice from John ilellenthal. Ge told them thig morming that thete are three other older claime nelghborlng their olatme and that the mineral righte were not included in the homertead patent.

numerous inqui tog are being mado here daily but nothing concrete seeme to be coming of them. It seeme to be more of a kind of interegt rather than a deaire to get out and prispect. lan y adrit that they will have to save a stake before attampting to go out.

Nothing further has developed about getting ua out of the offles other than the return of Raynor Brown from the etates, and hls gtop at juneau to talk with you about it. Curbstone rumor ha it thet wo ere out and thet it only remeine as a point of where we are to go. Everyone fears Mra. Hoppin for some reason or other, or thay give that lopreselon.

Hope thet ysu oan make your vieit goon 98 planned as I am truly anxious to gea you and talk to you. Nothing urgent of course.

This geems to be all for the prosent, so with regardo

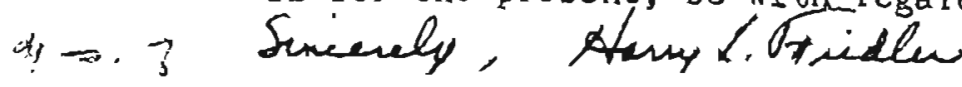


TERRITORY OF ALASKA

DEPARTMENT OF MINES

ASSAY OFFICE

Anchorage, Alaska, Jut y 26 19.46 REPORT OF ASSAY

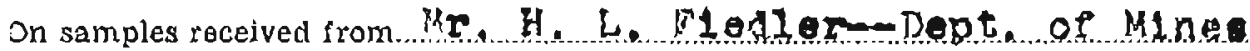
Address ...Anchorage. ....lanka

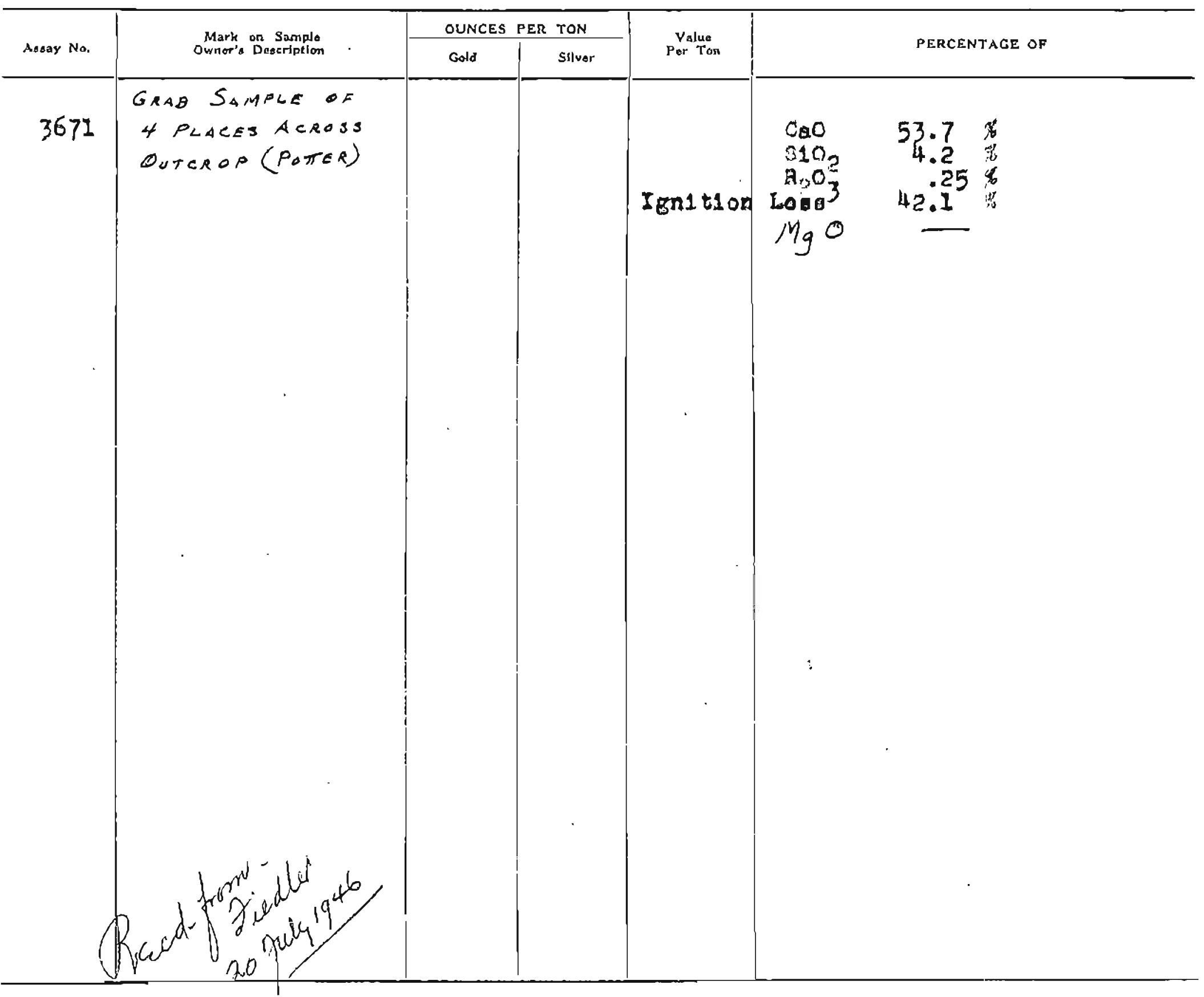

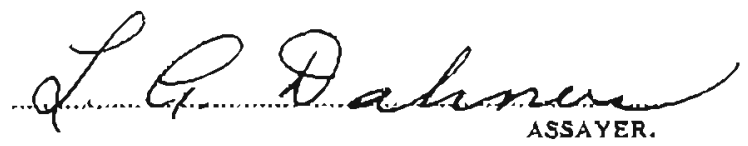




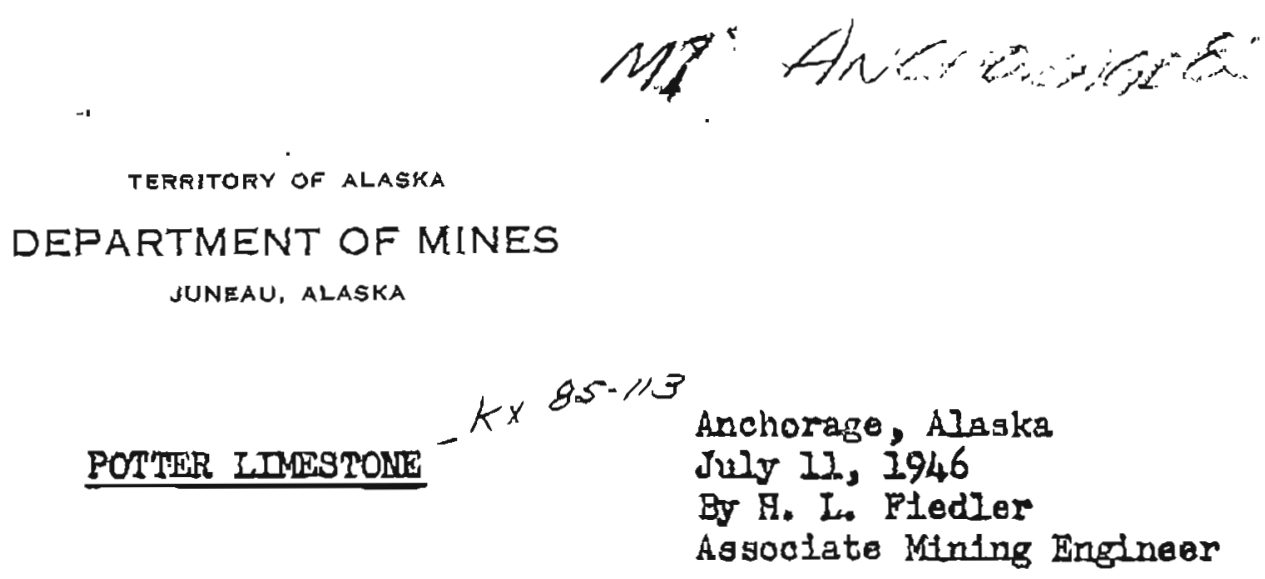

An outcropplng of 14 mestone is located at a point approximately east of mile 102.8 on the Alaska rallsoad, and about three miles northerly of the Potter Station. Access to the property $1 \mathrm{~s}$ by means of a rough road and trail from the rallroad at mile 103.5. A lore farm or homestend? 1. looated about one-half inlle from the radlroed on tho tra1l. The limestone outcrop is about two miles from the rallraad by tratl, or about one-half mile acrose an almost Impesagbie tidal plat fron the reilroad at milo 102.8.

The Ifmestone has been known for many yesrg, and probably prtor to 1915. It rae Iocated Apr1I 20, 1917 by Clarence R. and S. P. Bhodes. Minerel. Survey ras made Aaguot 24-26, 1923 , and patant isgued April 1, 1924, The area included in the olotm (The White Rock Placer Glind is 18.193 acres.

The Ifmotion cutcrop at the odge of gravel which appearg to be a terrace slong the shore of Turnggatn Arm and on the watrern alope of foothitis of the Cbugach Mountains. The general eloration of the terrace of banch Inmoliately to the east and noxth of the Ifwastone does not exceed 150 100t.

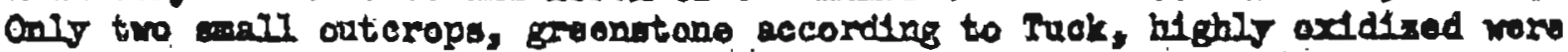
aoted to the weat of the Ifmetome, and none to the vent, at least for a distance of one-hale mile In, esah difrotion. The benah appeara to bu w-

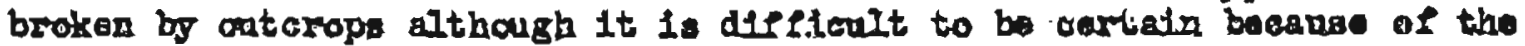
thiok anderbruah wiloh oavers the area. The 15mestone ontorop contacts a

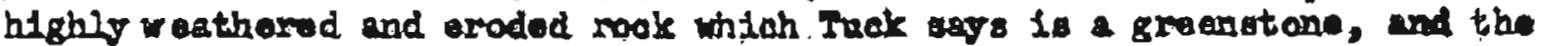

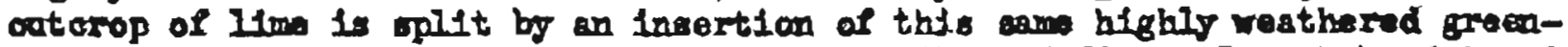
atone. It is frectured although a comon atrlke and dip could not be determined for the wole. The weathered greenatone contact ulth the watarn portion of the Ifmetane ahours gouge materlal about 3 inohed thlok, and appents to be matrly an tron minersl probably limontto.

1. Hand specimons of the Ijmestane show thin veinlets of calofte and wastrely arystalline etruotare. Querts seems to be more in evldenes in the rase on the veat afde of the outerep than on the east aide. Tho color Is a blue gray, and along ractures are statns of iron recelved probebly from the wathared greenatono adjolning.

Although no cops of USGS Bulletin 729b is avallabIe, selerenos in of flce notes is made that ithis bulletin tasohos on the Potter outarop. 
Potter Ifimestane, continued

It Is said that an unkmow amount of Ifmestone froin this looblity vas borned and used by earlies deg hereateaders as a satisfactory soll fartilliser, and also uaed an an ingrediont in the plaster used in the orfgenal high school bullding at Anchorage.

Very Ittile mork bas been dome on the dain or the one outorof of Itmo

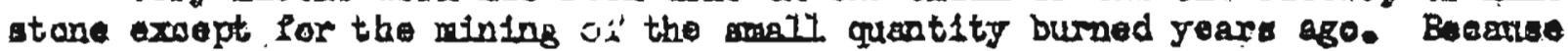
of the interest in IIm stone as a source for possiblo indiugtrial ased in this seation, a frogres of exploration ahould be oncouraged. Such a mograne

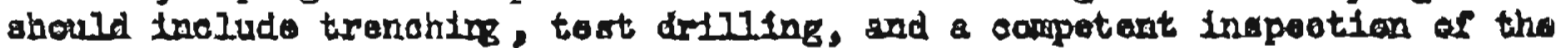
suriece for geologlaal detalli. Due to the heavy brish and loos mampy conditlons, the utmost diffloultios wil bo found to hinder this work in any rosonable short time.

The fact that the olnto is nor petented, the surrounding ares has been

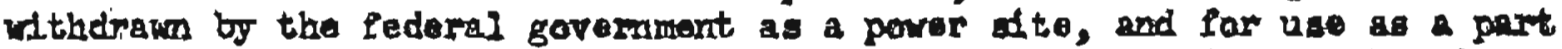

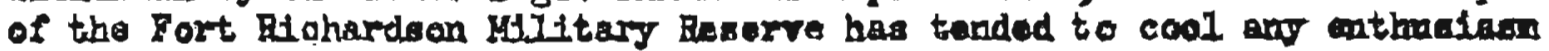

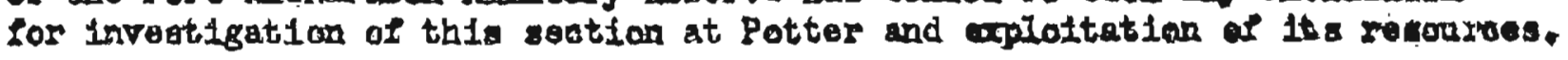




\section{FOPTER LIUESTONE.}

An outcroping of limestone 18 located at a potnt approximately east of mile 102.8 on the Alasice rail roed, and about three milea northerly of the potter Station. Access to the property is by means of a rough road and trall frors the rallroad at mile 103.5. A lone farre or homestead? io located about one-half mile from the railrogd on the trail. The limestone outorop is about two milea from the railroad by trall, or about one-half mile

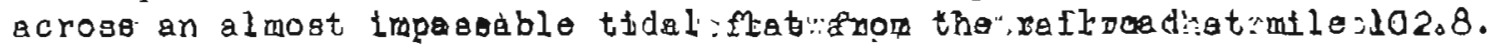

Fie limeatone has been known for many yeare, and probably prior to 1935. It was located Aprtl 20, 1917 by Clarence R. and S. F. Rhodea. istneraI Survey was de Auguat 24-26, 1923, and patent lasued April 1, 1924. The a ree included in the claim (The White Rook Placer Claim) is 18.193 acres.

The Limestone outcraps at the edge of grevel whloh appears to be a terrace along the shore of Turnege in Arm and on the western slope of foothille of the Chugach Mountalna. The general olevation of the terrace or bench lmmediately to the east and north of the llmestone does not exseed 150 feet. Only two srail outcrope, greenstone according to. Tuck, highly oxidized were noted to the rast of the limestone, and none to the west, at leat for a distance of one-half nile in each direction. 'The bench appears to bo unbroken by outcrops although it is diffleult to be oertain because of the thlck underbrush which coverg the ares. The limestone outcrop contacte a highly weathered and eroded rock which Tuck aaye is a greenetone, and the outcrop of lime le pplit by an ingertion of thtg samo highly weathered greenstone. It 1 e fractured al tho a cormon atrike and dip could not be determalned for the whole. The weathered greenstone contact with the weatern portion of the limetone showe gouge materlal about 3 inches thick, and appeare to be mainly an lron melneral probably libanito.

Fand specimens of the limestone show thin veinlete of calcite and megively cryatelilne structure. Quertz seeins to be nore in evidence in the so on the west alde of the outerop than on the eagt alde. The color la a blue gray, and along fratures are staing of Iron recelved probably from the weathered greeatone adjolning.

Al tho no copy of IJSGS Bulletin $792 b$ is available, a reference in office noteg is a de that this bulletin touches on the potter sutcrop.

It is seid that an anknown amount of linestone from this locality was burned and uaed by earlier day homesteaders as a satisfactory ool I fertilizer, and also used a an ingredient in the plaster used in the original high schosl building at Anchorage.

Very little work has been done on the claim or the one outcrop of limeatone except for the mining of the small quentlty burned years ago. Because of the interest in limestone as a source for posible industrial lasas in this aection, a program of exploration should be encouraged. Such a program 
should include trenching, test drilling, and a competent inspection of the gurface for geological detaila. Due to the heavy brush and local apampy conditions, the utinost difflculties will bo found to hinder this work in any reasoneble short time.

The fact that the clairo is now potented, the eurrounding area has been whthdrawn by the foderal government as a power site, and for use as a part of the lort Richerdson bilitary heserve has tanded to cool any enthuglasm for Investiggtion of this section at Patter and exploltation of ito resources.

Anchorage, Alaska July 11, 1946

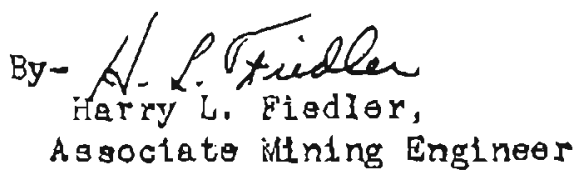

